
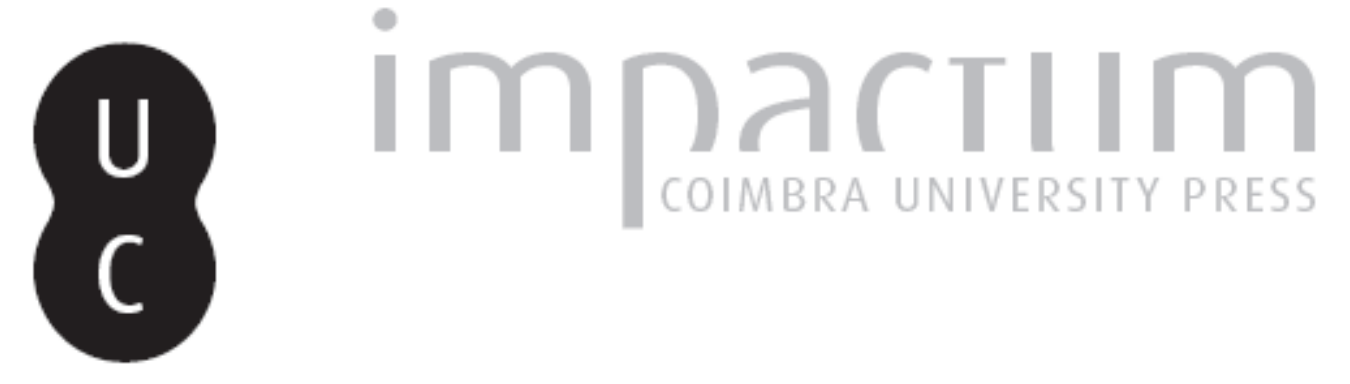

\title{
Plato's Ion and the Psychoanalytic theory of art
}

\author{
Autor(es): Konstan, David
}

Publicado por: Imprensa da Universidade de Coimbra

URL persistente:

URI:http://hdl.handle.net/10316.2/42239

DOI:

DOI:https://doi.org/10.14195/2183-4105_5_4

Accessed : $\quad$ 26-Apr-2023 16:14:48

A navegação consulta e descarregamento dos títulos inseridos nas Bibliotecas Digitais UC Digitalis, UC Pombalina e UC Impactum, pressupõem a aceitação plena e sem reservas dos Termos e Condições de Uso destas Bibliotecas Digitais, disponíveis em https://digitalis.uc.pt/pt-pt/termos.

Conforme exposto nos referidos Termos e Condições de Uso, o descarregamento de títulos de acesso restrito requer uma licença válida de autorização devendo o utilizador aceder ao(s) documento(s) a partir de um endereço de IP da instituição detentora da supramencionada licença.

Ao utilizador é apenas permitido o descarregamento para uso pessoal, pelo que o emprego do(s) título(s) descarregado(s) para outro fim, designadamente comercial, carece de autorização do respetivo autor ou editor da obra.

Na medida em que todas as obras da UC Digitalis se encontram protegidas pelo Código do Direito de Autor e Direitos Conexos e demais legislação aplicável, toda a cópia, parcial ou total, deste documento, nos casos em que é legalmente admitida, deverá conter ou fazer-se acompanhar por este aviso.

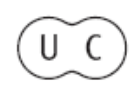




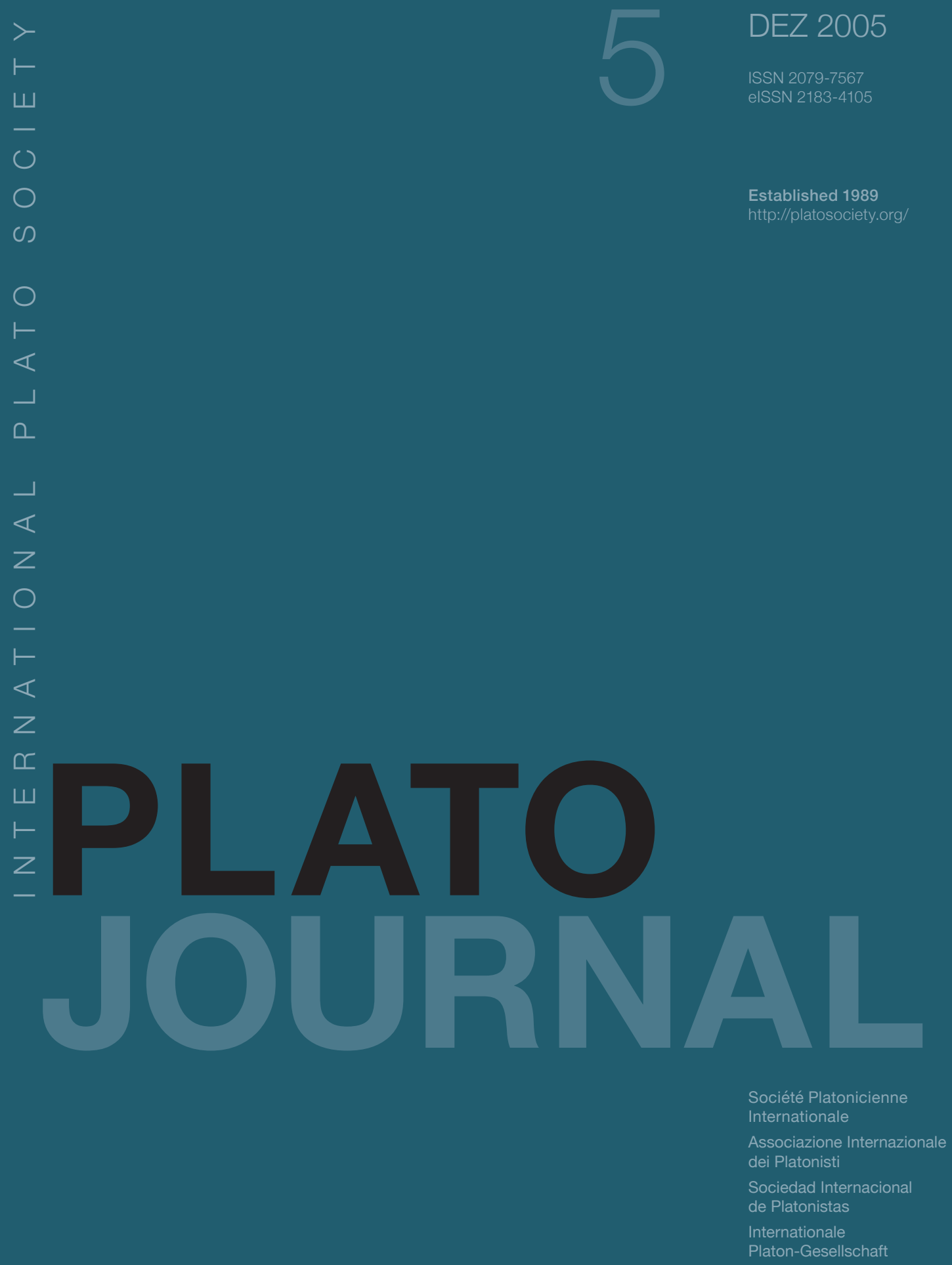




\section{Plato’s Ion And The Psychoanalytic TheOry OF ART ${ }^{1}$}

In Plato's Ion, a dialogue between Socrates and a rhapsode of that name, Socrates makes an extraordinary claim about poetic composition (533e-534a): “All good epic poets,” Socrates declares, "recite all their fine poems not by skill but because they are inspired and possessed, and the lyric poets do likewise. Just as corybants dance when they are not in their right minds, so too lyric poets compose their fine lyrics when they are not in their right minds. Rather, when they enter upon their harmonies and rhythms, they revel like bacchants and are possessed, just as bacchants draw honey and milk from rivers when they are possessed, and are not in their right minds. The souls of lyric poets do this as well, as they themselves affirm." There is a pun here on honey ( $\left.\mu \epsilon^{\prime} \lambda \iota\right)$ and lyrics ( $\left.\mu \epsilon^{\prime} \lambda \eta\right)$, but I wish to call attention to the vivid description of poetic enthusiasm that Plato puts in the mouth of Socrates, which goes far beyond the kind of inspiration that Homer and Hesiod ascribe to the Muses. ${ }^{2}$

This is not, of course, an isolated passage in the Platonic corpus. In the Apology (22b-c), Socrates finds that poets are less able to explain the meaning of their own compositions than the man in the street, and he concludes that "they did not compose what they did through skill, but rather by a kind of innate talent and inspiration, the way prophets and soothsayers do." In the Phaedrus (243e-245a), Socrates lists inspiration by the Muses as a form of madness ( $\mu a v i \alpha$ ), along with love, mantic enthusiasm (with a pun on manic), and a kind of mystical power of healing. Finally, in the Laws (719c), the Athenian asserts that "when a poet sits on the tripod of the Muses, then he is not in his right mind," and he does not know whether what he is saying is true or not. Good poetry, of the quality of the Homeric epics, seems to Plato, at least in these passages, to derive from a divine source, or at all events from some place that is different from our rational minds. ${ }^{3}$

It is a commonplace that the account of the soul that Plato develops in the Phaedrus and Republic is in certain respects analogous to the model or models elaborated by Freud and other theorists of modern psychoanalysis. Thus, Micaela Janan (1994: 7) notes that "the theory of the tripartite soul in Plato ... resembles the tripartite psyche mapped by Freud” (cf. also Ferrari 1987, Santas 1988, Price 1990). Janan adds that "Plato, Freud, and Lacan all explicitly theorize a connection between desire and creative art.” In what follows, I shall attempt to relate Plato's analysis of poetic creativity in the Ion to the psychoanalytic theory, or rather one psychoanalytic theory, of literary art. But that is not all. For Socrates, in the Ion, maintains not just that poets are inspired, but that singers of poetry, and those who hear them, are transported as well, each connected, in a famous image, like iron rings in a chain to the original magnetic source of energy, which is the god or Muse (535e-536d). What is more, Socrates applies this explanation not just to the rhapsodes' performance of poetry, but also to their ability to speak about the

\footnotetext{
1 This paper is a revised version of a talk given at the joint AIA-APA panel on "Images of Desire," held at the annual meeting of 2004.

${ }^{2}$ Hesiod says simply that the Muses taught him to sing (Works and Days 662; Theogony 22); Homer too indicates that the Muses inform the poet, since they know everything whereas mortals are ignorant (Iliad 2.484-86; cf. 2.761, 11.218, 14.508, 16.112; Odyssey 1.1, 8.480-81, 8.488).

3 This is not, of course, the doctrine that Plato professes in the Republic, where he criticizes poetry for purveying false opinions (2.377-82) and proposes to banish poets from his ideal city (10.605-07). As I indicate below, I do not regard the Ion as a precursor to Plato's attack on poetry in the Republic. For a more positive appreciation of Plato's view of mimetic poetry, see Halliwell 2002: 37-71; but cf. the reservations expressed in Konstan 2004.
} 
poetry they recite. Good poets, Ion says, interpret or represent ( $\dot{\epsilon} \rho \mu \eta \nu \in \dot{v} \omega)$ the things they receive from the gods, and rhapsodes in turn, Socrates adds, interpret the poets; they are thus

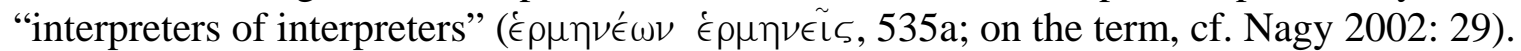
Socrates does not distinguish clearly between two senses of the word "interpret." On the one hand, we speak of a pianist interpreting a concerto by Mozart; on the other hand, we say a literary critic interprets a poem. Both meanings are relevant to the Ion. I shall defer this issue for the moment, however, and turn first to the inspiration of the poet.

Julia Kristeva, in her book, Revolution in Poetic Language (1974; English version 1984), draws on psychoanalytic theory (especially that of Jacques Lacan) to describe the nature of poetry and its relation to ordinary language. In brief, Kristeva distinguishes two modalities of the signifying process, which she labels the "semiotic" and the "symbolic" (23-24), and she maintains that "the dialectic between them determines the type of discourse" that results (24). By the symbolic, Kristeva (following Lacan) means the concepts or categories that underlie the linguistic and social order, and upon which the possibility of signification depends. The symbolic is structured, that is, it is organized by the conventions and regulations that inform ordinary life and language, whether these take the form of systems of kinship or syntactical laws. As Paul Allen Miller writes, "The Symbolic ... is the world of rules and codes. It includes language and all other shared semiotic systems,” including poetry (Miller 2004: 5). The semiotic, on the contrary (in Kristeva's particular sense of the term), is preverbal, and thus distinct from "symbolic operations that depend on language as a sign system" (27). Because the semiotic "precedes the establishment of the sign, it is not ... cognitive" (27). Borrowing a term from Plato's Timaeus, Kristeva calls the domain of such processes the chora (25), which she describes as a mobile set of operations that "precedes evidence, verisimilitude, spatiality, and temporality" (26). ${ }^{4}$ In Freudian terms, it is the space of the unconscious.

Kristeva understands good poetry to be an irruption of unconscious or semiotic processes into the logical order of language (the two domains, while analytically distinct, are always to some degree mixed). In Kristeva's words, "what remodels the symbolic order is always the influx of the semiotic" (1984: 62). In poetry, the chora intrudes upon and transgresses the symbolic order; however, it does not reduce it to "'romantic' folly, pure madness" (82). That is, poetry remains coherent and continues to signify; or, as Miller (2004: 5) puts it in reference to Lacan: "Poetry as a linguistic practice takes place in the Symbolic." But it infuses the symbolic with material from the chora. Modernist literature in particular, according to Kristeva, "moves beyond madness and realism in a leap that maintains both 'delirium' and 'logic”” (ibid.).

The reader will have by now divined what I am about to suggest, namely that Kristeva's idea of the chora and the semiotic corresponds to Plato's vision of the mental state of divinely inspired poets, who "are not in their right minds" but rather "revel like bacchants and are

\footnotetext{
${ }^{4}$ One of the anonymous referees for this paper points out that in the Timaeus the chora "functions as the antithesis to the divine," whereas in Plato's Ion "the province of inspiration is the divine.” In fact, Plato's chora is the lowest of three kinds of unchanging entity, and it "provides a location [ $[\ddot{\delta} \delta \rho \alpha$ ] for all things that come to be. It is apprehended by a kind of bastard reasoning that does not involve sense perception, and it is hardly even an object of

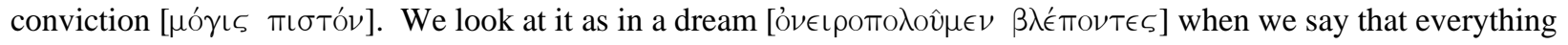

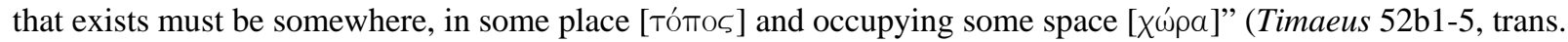
Zeyl 1997: 1255). The dreamlike quality that Plato associates with the chora may have induced Kristeva to choose the term as the name for the precognitive state or unconscious.
} 
possessed." Like Plato, Kristeva too sees a continuity between "shamanism, esoterism, the carnival and 'incomprehensible' poetry," all of which, she says, testify to what "socially useful discourse" represses, that is, those processes that exceed our "communicative structures" (16).

There are other possible accounts of the ecstatic state of the poet during the process of composition, as Socrates describes it, that do not necessarily invoke the doctrine of the tripartite or even bipartite soul. The Ion takes its point of departure from the curious fact that Ion both performs and discourses upon the Homeric epics brilliantly, but falls asleep at the mere mention of other good poets, such as Hesiod and Archilochus (531a; cf. 536b-c). The hypothesis of poetic possession is introduced to explain this puzzle: whether as performer or as critic, Ion must be inspired when it comes to Homer, like an iron ring charged by a magnet; for if it were a matter of skill, then he should be able to recite and explain all poets alike, whether good or bad, since they generally speak about the same kinds of things, such as wars, councils, heaven and Hades, gods and heroes (531c). Poets too, Socrates adds, may hit or miss, which would not be the case if composition were a technê (534d, the example of Tynnichus).

In a second strand of the argument, which comes to the fore in the last third of the dialogue, Socrates changes tack. Instead of arguing that a specialist should be able to talk intelligently about any product of his art, he says that if poetry, as Ion maintains (536e), provides wisdom on all subjects, then the specialist in each - whether horseracing, prophecy, medicine, architecture, or warcraft - should be best qualified to speak about how well they are represented, and not the rhapsode, whose expertise resides in the rhapsode's art (538c, 539e-540a). Here, the emphasis shifts from the poet to what we might call the critic or interpreter; this is why Plato chose a rhapsode as Socrates' interlocutor rather than a poet. Socrates' view of criticism is restricted to explicating technical matters within a poem, in response to the assumption, evidently plausible in antiquity, that poets were reliable founts of wisdom on everything. Now, Ion might have answered at this point that he can lecture well on the nature of performance, which is what the rhapsode's art is about (cf. Janaway 1995: 31-32). Instead, however, he bows to Socrates' conclusion that, though he has no skilled knowledge, he can say many fine things about Homer because he is possessed by divine dispensation (542a).

What kinds of things is Ion able to say about Homer? Plato’s Socrates never gives him the opportunity to show his stuff, but the argument so far would seem to suggest that he can, in fact, discourse capably on all the arts that Homer touches on, even though he is master of none of them. If this is the case, then what he gains from the god is the facility to speak as though he knew what he was talking about, although in fact he does not. And if this is what inspiration means for the critic, it should be similar in the case of the poet: what the poet achieves through inspiration is the knack of sounding as though he knows everything, or that his characters do, whereas he really does not. Inspiration, on this account, is nothing but a curious ability to mimic the way an expert sounds, the production of a simulacrum of true discourse, but not based on technical knowledge. As John Ferrari (1989: 94) writes, the dialogue leads one to doubt "whether the understanding which the poets claim to transmit by virtue of divine afflatus, and which seems to be embodied in the rhapsode's interpretation of the poet's thought, is anything more than an appearance of understanding." All that Ion knows, on this view, is "what is suitable for one talking about Homer to say” (96). In Kristeva’s terms (95), Ion, when possessed, 
speaks a metalanguage; thus, despite his ignorance of Homeric generalship, he, like Homer, can describe how good generals speak and act, thanks to divine inspiration.

Although this interpretation has much to be said for it, it scarcely does justice to the notion that the gods and Muses are the source of great poetry, or to the ecstasy that seizes poets, performers, and audience when a masterpiece is produced - though it must be said that Ion rejects Socrates' description of him (536d), and he is in fact capable of paying strict attention to the audience's reaction while he performs (535e). If all that happens is that a simulation is taken for the real thing, the gods would stand accused of deceiving human beings. We may recall that Socrates equates poetic enthusiasm with that of prophets - and not false ones. To be sure, inspired seers do not necessarily understand the meaning of the oracles they deliver, but what they utter is not just an imitation of how someone skilled in the mantic art would talk. Socrates has intimated the possibility of a deeper meaning to poetry, akin to prophetic wisdom, even as it unites poet, performer and public in an exalted frenzy.

Socrates accepts that there is a rational content to good poetry, and that masters of the several crafts can evaluate its accuracy in their own domains. At the level of mimesis, poetry is not mystical or riddling in nature but fully comprehensible. As Miller says: "Poetry as a linguistic practice takes place in the Symbolic.” Nevertheless, poetry is produced and enjoyed by way of a suspension of reason. Insofar as divine madness informs the poetry itself, it can be said to intrude upon the symbolic, to use Kristeva's term.

If this is so, then poetry and interpretation, to the extent that they are inspired, are neither "delirium" - that is, Corybantic madness - nor "logic," but a mixed discourse that corresponds to what Kristeva calls a "text," in which the drives "triggered within the chora" intersect with the symbolic "in an endless rhythm” (99). Perhaps the curious doubling in Ion's state of consciousness, in which he is simultaneously carried away by the story he recites and yet coolly aware of the audience's reaction, is a symptom of this textual fluctuation. ${ }^{5}$ Kristeva reserves the term "text" for certain kinds of modern literature, but this seems an unnecessary limitation. All good poetry is like this, and exegesis as well, for Plato's analysis eliminates the difference between them. Both take place in the space where the semiotic infuses the symbolic with particular intensity. The difference between literature and criticism becomes, in the words of Paul de Man (1979: 19), “delusive.”6

The Ion is a spare dialogue, and Plato does not develop his idea of inspired poetry in any detail, apart from indicating the spell it casts on the poet, rhapsode, and audience. Does Socrates mean to ascribe a kind of truth to poetry? Although neither poets nor rhapsodes have wisdom, it is possible that poems do; Socrates seems to suggest as much in the Apology. But the

\footnotetext{
${ }^{5}$ See Jannaway 1995: 22-23, and cf. Schechner 1985: 110, 1988: 274, on the split consciousness described by modern actors; Lucian On the Dance 83-84 reports that an actor too identified with his role went mad - he was representing the mad Ajax; cf. Webb forthcoming.

${ }^{6}$ With the idea of a "text," Kristeva most clearly transcends the familiar dichotomy in Romantic theories of art between the rational and the non-rational; cf. Agamben 1999: 113: "In the Western Literary Tradition, the act of poetic creation and, indeed, perhaps every act of speech implies something like a desubjectification (poets have named this desubjectification the 'Muse')." For Kristeva, as for Plato, not just poetic composition, but exegesis too can be said to be inspired. Romantic theories of inspiration do not, I think, address this question.
} 
Ion leaves this moot. ${ }^{7}$ Ferrari (1989: 98) suggests that Plato focuses rather on "theatricality," that is, a "capacity for imaginative identification" that is inspired in poets, performers and audiences. We might venture, too, that poetry entrances by its sensuousness, and that its effect is bound up with spectacle, down to the showiness Ion's elaborate rhapsodic regalia (535c-d), the perceptible counterpart to the vividness or enargeia by which poets made the narrative visible to the mind's eye. But there is also in Plato's Ion at least an intimation of the view that inspired poetry and interpretation, in both senses of the word, manifest themselves as rational discourse but are penetrated or molded by processes that are non-rational and "precede the establishment of the sign." If so, then the Ion points the way no so much to the attack on poetry in the Republic (so, e.g., Woodruff 1983, Janaway 1995: 28; cf. Ledbetter 2003: 81, 92), as to a positive appreciation of its capacity to open a window onto meanings beyond the symbolic - that is, conditioned by processes that precede "evidence, verisimilitude, spatiality, and temporality."

\author{
David KONSTAN \\ Brown University
}

\footnotetext{
7 I disagree with Partee 1981: 34 that “The Ion admits only the rhapsode’s rapture, not his perception of realities or his value as a teacher"; for in his rapture the rhapsode speaks correctly about the poem. Janaway 1995: 33 argues that "Plato is not looking to the divine source of poetry as an explanation of its truth or wisdom - rather as an explanation of its fineness as poetry, which he identifies as a distinct question" (cf. Ledbetter 2003: 85, 94-98). But to speak well or finely about poetry is to know the poet's dianoia, as Nagy says (2002: 29). To say that Ion speaks well about the fineness of Homer's poetry still leaves unexplained why he has nothing to say about the artistic quality of other poets.
} 


\section{BIBLIOGRAPHY}

Agamben, Giorgio. 1999. "Shame, or On the Subject." In Remnants of Auschwitz: The Witness and Archive, trans. Daniel Heller-Roazen (New York: Zone Books) 87-135.

De Man, Paul. 1979. Allegories of Reading: Figural Language in Rousseau, Nietzsche, Rilke, and Proust. New Haven: Yale University Press.

Ferrari, John. 1987. Listening to the Cicadas: A Study of Plato's Phaedrus. Cambridge: Cambridge University Press.

Halliwell, Stephen. 2002. The Aesthetics of Mimesis: Ancient Texts and Modern Problems. Princeton: Princeton University Press.

Janan, Micaela, “When the Lamp is Shattered”: Desire and Narrative in Catullus (Carbondale: Southern Illionois U.P., 1994).

Janaway, Christopher. 1995. Images of Excellence: Plato's Critique of the Arts. Oxford: Clarendon Press.

Konstan, David. 2004. “The Two Faces of Mimesis.” Review of Halliwell 2002. Philosophical Quarterly 54: 301-08.

Kristeva, Julia, Revolution in Poetic Language, trans. Margaret Waller (New York: Columbia U.P., 1984).

Ledbetter, Grace M. 2003. Poetics before Plato: Interpretation and Authority in Early Greek Theories of Poetry. Princeton: University Press.

Miller, Paul Allen. 2004. Subjecting Verses: Latin Love Elegy and the Emergence of the Real. Princeton: Princeton University Press.

Nagy, Gregory. 1999. "Homer and Plato at the Panathenaia: Synchronic and Diachronic Perspectives.” In Thomas M. Falkner, Nancy Felson, and David Konstan, edd., Contextualizing Classics: Ideology, Performance, Dialogue. Essays in Honor of John J. Peradotto (Lanham, MD: Rowman \& Littlefield) 123-50.

Nagy, Gregory. 2002. Plato's Rhapsody and Homer's Music: The Poetics of the Panathenaic Festival in Classical Athens. Washington, D.C.: Center for Hellenic Studies.

Partee, Morriss Henry. 1981. Plato’s Poetics: The Authority of Beauty. Salt Lake City: University of Utah Press.

Price, Anthony. 1990. "Plato and Freud.” In Christopher Gill, ed., The Person and the Human Mind: Issues in Ancient and Modern Philosophy (Oxford: Clarendon Press) 247-70. 
Russell, D.A., trans., Plato' Ion, in D.A. Russell and M. Winterbottom, edd., Ancient Literary Criticism: The Principal Texts in New Translations (Oxford: Oxford U.P., 1972) 39-50.

Santas, Gerasimos. 1988. Plato and Freud: Two Theories of Love. Oxford: Blackwell.

Schechner, Richard. 1985. Between Theater and Anthropology. Philadelphia: University of Pennsylvania Press.

Schechner, Richard. 1988. Performance Theory. Rev. ed. New York: Routledge.

Tigerstedt, Eugáene N. 1969. Plato’s Idea of Poetical Inspiration. Helsinki: Centraltryckeriet.

Tigerstedt, Eugáene N. 1970. "Furor Poeticus: Poetic Inspiration in Greek Literature before Democritus and Plato.” Journal of the History of Ideas 31: 163-78.

Webb, Ruth. forthcoming. "Fiction, Mimesis and the Performance of the Greek Past in the Second Sophistic.” In David Konstan and Suzanne Saïd, edd., Greeks on Greekness. Proceedings of the Cambridge Philological Society.

Woodruff, Paul, trans. 1983. Plato, Two Comic Dialogues: Ion and Hippias Major. Indianapolis: Hackett.

Zeyl, Douglas J., trans. 1997. “Timaeus.” In John M. Cooper and Doublas S. Hutchinson, edd., Plato: Complete Works (Indianapolis: Hackett) 1125-91. 